\title{
Redenomination Policy and Economic Perfomance: Experimental and Historical Approach
}

\author{
Falikhakh Nur Baeti ${ }^{1}$, Bambang Juanda ${ }^{2}$, Alla Asmara ${ }^{3}$
}

\begin{abstract}
The discourse of redenomination policy has existed since 2010. This research analyzes the impact of economic growth, type of goods, transitions period and redenomination stages towards economic performance which measured from the change in the price of transactions and the number of transactions. This research used primary data and secondary data; the primary data was collected through the experimental economy. The percentage of the change in the price of transactions after redenomination in low economic growth condition showed an increase, while in high economic growth condition showed a decrease. Secondary data was gathered to analyze the deciding factor in the success of redenomination through logistic analysis method. The result showed that the variable of economic growth, unemployment rate and the level of democratization in a country affect the success of the implementation of redenomination.
\end{abstract}

Keywords: redenomination, economic performance, economic experimental, logistic regression

\begin{abstract}
Abstrak
Adanya wacana kebijakan redenominasi telah ada sejak 2010. Penelitian ini menganalisis pengaruh pertumbuhan ekonomi, jenis barang, masa transisi dan tahapan redenomination terhadap kinerja perekonomian yang diukur dengan harga transaksi dan jumlah transaksi. Penelitian ini menggunakan data primer dan data sekunder, data primer dikumpulkan dengan menggunakan percobaan ekonomi. Persentase perubahan harga transaksi setelah redenomination pada kondisi pertumbuhan rendah menyebabkan kenaikan harga transaksi sedangkan pada pertumbuhan tinggi menyebabakan penurunan harga transaksi. Data sekunder dikumpulkan untuk menganalisis faktor apa saja yang memengaruhi keberhasilan kebijakan redenomination melalui metode regresi logistic. Hasilnya menunjukkan bahwa variabel pertumbuhan ekonomi, tingkat pengangguran dan tingkat demokratisasi suatu negara memengaruhi keberhasilan kebijakan redenomination.
\end{abstract}

Kata Kunci: redenominasi, kinerja perekonomian, percobaan ekonomi, regresi logistik

How to Cite:

Baeti, F. N., Juanda, B., \& Asmara, A. (2018). Redenomination Policy and Economic Performance: Experimental and Historical Approach. Signifikan: Jurnal Ilmu Ekonomi. Vol. 7 (2): 173 - 184. doi: http//dx.doi.org/10.15408/ sjie.v7i2.6568. 


\section{Introduction}

The simplification and equalization of rupiah value or redenomination have become a discourse after former Bank of Indonesia (BI) governor Darmin Nasution threw the discussion on August 3rd, 2010. The discourse of redenomination policy has existed since 2010, but in 2016 with the submission of the Bill of Price Changes to Proglenas the policy reappeared. Redenomination policy based on by the number of digits that caused too much inefficiency. Also, the Rupiah included into the garbage money that is added to the top 10 of the weakest exchange rate in the world. Therefore, it is necessary to increase the credibility of the rupiah currency in the eyes of the world. Also, the failure and success of redenomination policies are also influenced by other factors at a time when the country is implementing a redenomination policy.

Indonesian currency includes ten garbage's money, which has the third lowest exchange rate in the world and the lowest in Asia-Pacific region after Vietnam (World Economic Forum, 2016). The number of digits is too much being a problem for the Indonesian government to create a policy that can increase the credibility of the value of Indonesian currency in the world. One of the policies that can support the credibility of the currency is the currency redenomination policy. Those because the redenomination policy will facilitate the credibility of the rupiah compared to other countries' currencies in areas that will further build public pride in the rupiah currency.

The reason for this policy is because the number of digits that are too large ever occurred in Zimbabwe's country. High inflation (the value of money has decreased significantly) makes consumers have to bring enough money to shop. Also, large fractions cause inefficiency in accounting writing, and most importantly large denominations can also reduce the credibility of the currency internationally. The impact of the low credibility of the rupiah currency globally is the occurrence of currency substitution or transition of rupiah usage in every transaction to US dollar.

Currency substitution on a certain scale has occurred in Indonesia, where purchases for certain products use US dollar because transactions use rupiah is inefficient, also the low credibility of the rupiah currency, and the difficulty of converting from rupiah to US dollar. Several countries have practiced redenomination, among these countries, there are countries that failed and succeed in redenomination. The indicator successful redenomination saw from the low Inflation rate and high economic growth.

On the other side, Turkey is one of the countries that successfully implement redenomination policy, which after the redenomination policy made Turkey's inflation stabilized at the rate at 8 to 9 percent. Based on the history of countries that have done the redenomination, there are important things to be noted, namely transition period. The concept of the transitional period that is the period in which two currencies used which are the terms of the old currency and the currency of redenomination called the new currency. At this time also the central bank has printed a new money redenomination policy. Mahardika et al. (2015) state that in estimating the value of a good is more volatile and inaccurate when using a new currency with the rapid transition period so that the transition period on the 
implementation of redenomination policy will affect the performance of the economy at that time.

According to Mosley (2005) indicator of success redenomination seen from the level of low Inflation and high economic growth after redenomination policy is applied. Based on historical data, some countries have practiced redenomination, among these countries; some countries failed and succeed in implementing redenomination policy. One of the countries considered to be failing is Zimbabwe. The policy to cut the 9 Zimbabwe's dollar zero in middle of 2006 caused hyperinflation about 1097 percent more than the previous year by 30 percent.

For this policy, it is necessary to examine the effect of economic growth, the type of goods, the transition period and the redenomination stage on the price of transactions and the number of transactions through economic experiments. In addition to using economic experiments to see the implications of redenomination policies on transaction prices and the number of transactions, this study also aims to determine the factors that influence a country's success in implementing redenomination policies.

\section{Method}

To analyze the impact of redenomination stages on economic performance use Least Significant Difference (LSD). Meanwhile to examine the success factors of redenomination policy is by using logistic regression. The data used in this research are primary data and secondary data. The primary data collected in this research obtained through experiment simulation. The primary data collected is a description of the responses of the research subjects (simulators) as economic actors in experiments that can see from decisions that are made by experimental actors. While for secondary data obtained from Inflation data, economic growth, interest rate, money growth, unemployment rate, democratisation index of 32 countries either redenomination or non-redenomination from 1963-2008 (See Appendix). Secondary data obtained from World Development Indicators published by World Bank, International Monetary Fund and Center for Systemic Peace. Primary data collected through this experimental design aims to examine how the effect of economic growth, the type of goods and the transition period to the transaction price and the number of transactions, so that the response variable $(\mathrm{Y})$ is the price and the number of transactions. The other factors included in this research are inflation and economic growth. The research was conducted an experimental economic method (laboratory study) using a posted system.

This study uses students as research subjects, especially those who know about economic principles. Respondents were selected using convenience-sampling technique. This technique is also called random sampling or accidental sampling, that is the procedure of selecting the most easily available, arbitrary or accidental sample (Juanda, 2009). This technique produces subjective characteristic of the respondent, but this has been overcome. The existence of the appropriate use of media rewards (Induce value theory) makes certain economic actors and congenital characteristics uninfluenced (irrelevant). The existence of reward method based on the theory of induced value caused the other variables that may 
affect the response will be controlled or has not been affected by other factors. So the data is better to assess the impact of a policy on the behavior of economic actors than data from the survey (Juanda, 2011).

The reason that is observed in this study refers to the research of Juanda (2009) which is in the form of sale and purchase transactions with market system Posted Offer. The post-offer transaction system is a transactional system commonly encountered in the field of retail and industrial businesses which is prices that have been installed by the seller and then offered to the buyer (posted-offer price), and buyers just choose the desired goods based on their budget. Factors that are observed the effect on the observed response are: First, economic growth, consisting of two levels, namely: (a) low economic growth; and (b) high economic growth. Second, type of goods consists of two levels, namely: (a) Inelastic: and (b) elastic. Third, the transition period consists of two levels: (a) rapid transition; and (b) the old transition. Fourth, stages of redenomination, consisting of two levels, namely: (a) direct; and (b) gradually.

The analysis used to analyze the factors that influence the success of redenomination is a logistic regression. The logit model is a non-linear regression model that produces an equation where the dependent variable is categorical. The most basic category of the model produces binary values such as the numbers 0 and 1 . The resulting number is the number that can represent a certain category that is resulted from the probability calculation of the occurrence of a particular category. The basic form of probability in the logit model is $\mathrm{Yi}=$ $0(1-\mathrm{Pi})$ and $1(\mathrm{Pi})$. Systematically, logit regression models are used to assess the factors that influence redenomination success. Logit regression model referred to in this research is as follows:

$W_{i}=W_{n}\left(\frac{P i}{1-P_{i}}\right)=\beta_{0}+\beta_{1} \operatorname{Inf}_{i}+\beta_{2}$ Gro $_{i}+\beta_{3} \operatorname{Int}_{i}+\beta_{4}$ Mon $_{i}+\beta_{5} \operatorname{Unp}_{i}+\beta_{6}$ Dem $_{i}$

$\mathrm{W}_{\mathrm{i}}=$ The state's success in applying redenomination policies (worth 1 for "succeed" and 0 for "failure")

$\mathrm{Inf}_{\mathrm{i}}=$ Dummy inflation rate of country of $\mathrm{i}$ in year applied redenomination policy

$\mathrm{Gro}_{\mathrm{i}}=$ Dummy economic growth rate of country of $\mathrm{i}$ in year applied redenomination policy

Int $_{\mathrm{i}}=$ Dummy interest rate of country of $\mathrm{i}$ in year applied redenomination policy

Mon $_{\mathrm{i}}=$ Dummy money growth of country of $\mathrm{i}$ in year applied redenomination policy

$\mathrm{Unp}_{\mathrm{i}}=$ Dummy unemployment rate of country of $\mathrm{i}$ in year applied redenomination policy

Dem $_{\mathrm{i}}=$ Dummy demokratitation rate of country of $\mathrm{i}$ in year applied redenomination policy

This middle-value difference test is used to analyze the primary data aimed at knowing the differences between population groups of each treatment combination. According to Mattjik and Sumertajaya (2002), the data diversity conditions of the two populations can distinguish into two; there is the same diversity (homogeneous) or $\sigma 12=\sigma 22=\sigma 2$ and unequal (heterogeneous) or $\sigma 12 \neq \sigma 22 \neq \sigma 2$ diversity. If the same variety then tested by statistic test as follows:

$$
\left|t_{\text {hit }}\right|=\frac{\left|\bar{x}_{1}-\bar{x}_{2}\right|-\left|\mu_{1}-\mu_{2}\right|}{\sqrt{\frac{s_{g a b}^{2}}{n_{1}}+\frac{s_{g a b}^{2}}{n_{2}}}} \text {, where }
$$




$$
s_{g a b}^{2}=\frac{\left(n_{1}-1\right) s_{1}^{2}+\left(n_{2}-1\right) s_{2}^{2}}{n_{1}+n_{2}-2} \text { and d.b }=n_{1}+n_{2}-2
$$

Rejection criteria is H0 if $\left|t_{\text {hit }}\right|>t_{\mathrm{tab}(\alpha, \mathrm{db})}$ otherwise.

While if unequal diversity, so it is tested by statistic test as below:

$$
\begin{array}{r}
\left|t_{\text {calc }}\right|=\frac{\left|\bar{x}_{1}-\bar{x}_{2}\right|-\left|\mu_{1}-\mu_{2}\right|}{\sqrt{\frac{s_{1}^{2}}{n_{1}}+\frac{s_{2}^{2}}{n_{2}}}} \text { and } \\
d . b=\frac{\left(\frac{s_{1}^{2}}{n_{1}}+\frac{s_{2}^{2}}{n_{2}}\right)}{\frac{\left(s_{1}^{2} / n_{1}\right)^{2}}{n_{1}-1}+\frac{\left(s_{2}^{2} / n_{2}\right)^{2}}{n_{2}-1}}
\end{array}
$$

Rejection criteria is H0 if $\left|t_{\text {hit }}\right| \geq t_{\text {tab }(\alpha, \mathrm{db})}$ otherwise.

Where:

$\bar{x}_{1}=$ middle value of unit for the first sample

$\bar{x}_{2}=$ middle value of unit for the second sample

$\mu_{1}=$ middle value of the first population

$\mu_{2}=$ middle value of the second population

$s_{1}^{2}=$ diversity of the first sample

$s_{2}^{2}=$ diversity of the second sample

$n_{1}$ = amount of unit for the first sample

$n_{2}$ = amount of unit for the second sample

\section{Result and Discussion}

Some researchers have done previous research on redenomination. Zidek and Michal (2015) had made the impact of redenomination in Turkey leads to a decrease in the inflation rate, but the redenomination process has some other effect, namely an increase in transactions, an increase in these transactions will also improve the accounting system. In addition, the psychological effects (perceptions) of society on this policy tend to be good. Then, previous research was done by Dzokoto et al. (2010). This study analyzes the existence of money illusion that occurred in Ghana after the redenomination policy. The results of this study indicate that a change in the use of the old currency into the new currency will affect the level of self-worth determination, the trivialization of price increases, changes in consumer behavior. This is because of the money illusion where they feel the difference in the real value of the new currency with the old currency. A person's tendency to judge money in a nominal form more than the real value.

Other research is also done by Mehdi and Motiee (2012) analyzing redenomination in Iran. Redenomination is a serious policy that needs to be done by Iran given Iran's inflation rate is very high in the last four decades as well as the government budget deficit. From some literature of this journal indicates that redenomination will have a positive effect on economic growth, and the strengthening of the nominal value of the currency, but does not affect 
people's purchasing power and purchasing power of goods. On the Other Side, Mahardika et al. (2015) had done the study to see the impact of individual consumption behavior in the face of redenomination. The results show that the public in estimating the value of a good is significantly more volatile and inaccurate when using money in new currency if redenomination policy is done without a transitional period.

Redenomination very closely related to money illusion. The impact that can occur in the application of redenomination is the emergence of a psychological bias called money illusion. This illusion can arise because of the nominal price change of goods due to redenomination. Most people will perceive that the price of the goods becomes cheaper because of the removal of the zero value of the previous currency. Hobijn et al. (2006) also state that there has been money illusion in the European countries that have made currency changes into Euro. Euro is nominal fewer than the previous currency felt cheaper by the public. Hobijn et al. (2006) argue that price increases after redenomination can be explained by the general model of the cost of menu prices, by incorporating company decisions when they adopt a new currency.

Two possibilities will occur after this policy is implemented: first, the prices of goods are restrained and stable, then the second possibility of the price of goods to rise. Redenomination is referred to in this study is the redenomination policy to eliminate four zeros number. Table 1 shows that growth conditions (low growth and high growth) have significant value in influencing the change in transaction price. The percentage change in transaction price at low growth conditions increased by 0.71 percent while in high growth conditions the transaction price decreased by 0.62 percent. This indicates that high economic growth conditions are a good condition used to implement redenomination policies rather than low economic growth conditions.

The type of goods also determines the price changes after redenomination, in the inelastic goods the percentage of price changes increases after redenomination, while for elastic products tends to decrease after redenomination. This is because the seller of the inelastic goods wants a more significant profit, considering the nature of inelastic goods is a primary necessity item that will remain purchased even though the price increases. While the percentage change in transaction price on elastic products after redenomination decreased. This result is by the research of Pambudi et al. (2015) and Astrini (2014).

Also, to economic growth factors, the redenomination stage also significantly affect the percentage change in transaction prices. Table 1 shows that straight redenomination tends to be better. This is because the redenomination policy is done in stages the percentage of price changes increased greater by 0.60 percent than the redenomination policy that is directly done that is decreased by 0.50 percent. Changes in transaction price due to the type of goods based on Table 1 depend on growth (there is interaction). However, based on Table 1 there is a group that has significant differences in its effect on the transaction price. Redenomination is performed during times of high economic growth has a significantly different impact on changes in transaction prices on the type of goods (inelastic and elastic). In inelastic goods, the percentage change in transaction price increased by 0.59 percent, while in the elastic goods the percentage of transaction price change decreased by 1.56 percent. These results are consistent with previous results despite being imposed on conditions of high economic growth. 
Falikhakh Nur Baeti

Redenomination Policy and Economic Performance

Table 1 Least significant difference (LSD) between the percentage value of the transaction price change and the percentage change in the number of transactions

\begin{tabular}{|c|c|c|c|c|c|c|}
\hline \multirow[b]{2}{*}{ Condition } & \multicolumn{3}{|c|}{ Change in Price of Transaction } & \multicolumn{3}{|c|}{ Change in Amount of Transaction } \\
\hline & variety & $\begin{array}{l}\text { Presentation } \\
\text { Change }\end{array}$ & $p$-value & variety & $\begin{array}{l}\text { Presentation } \\
\text { Change }\end{array}$ & $P$-value \\
\hline $\begin{array}{l}\text { Low growth } \\
\text { High growth }\end{array}$ & same & $\begin{array}{r}0.71 \\
-0.62\end{array}$ & $0.038^{*}$ & unequal & $\begin{array}{l}-0.66 \\
-0.48\end{array}$ & 0.541 \\
\hline $\begin{array}{l}\text { Inelastic goods } \\
\text { Elastic goods }\end{array}$ & Same & $\begin{array}{r}0.31 \\
-0.21\end{array}$ & 0.247 & unequal & $\begin{array}{l}-2.1 \\
0.99\end{array}$ & $0.03^{*}$ \\
\hline $\begin{array}{l}\text { Short transition period } \\
\text { Long transition period }\end{array}$ & Same & $\begin{array}{l}0.09 \\
0.01\end{array}$ & 0.460 & same & $\begin{array}{l}-0.29 \\
-0.85\end{array}$ & 0371 \\
\hline $\begin{array}{l}\text { Direct redenomination } \\
\text { Gradual redenomination }\end{array}$ & Same & $\begin{array}{r}-0.50 \\
0.60\end{array}$ & $0.072 *$ & Same & $\begin{array}{r}0.56 \\
-1.70\end{array}$ & 0.182 \\
\hline $\begin{array}{l}\text { Low growth; inelastic goods } \\
\text { Low growth; elastic goods }\end{array}$ & unequal & $\begin{array}{r}1.38 \\
-2.71\end{array}$ & 0.197 & unequal & $\begin{array}{l}-2.7 \\
1.39\end{array}$ & $0.068^{*}$ \\
\hline $\begin{array}{l}\text { High growth; inelastic goods } \\
\text { High growth; elastic goods }\end{array}$ & same & $\begin{array}{r}0.59 \\
-1.56\end{array}$ & $0.053^{*}$ & unequal & $\begin{array}{r}-1.56 \\
0.60\end{array}$ & 0.148 \\
\hline $\begin{array}{l}\text { Inelastic goods; low growth } \\
\text { Inelastic goods; high growth }\end{array}$ & same & $\begin{array}{l}1.38 \\
0.59\end{array}$ & $0.041^{*}$ & same & $\begin{array}{r}-1.56 \\
-2.7\end{array}$ & 0.352 \\
\hline $\begin{array}{l}\text { Elastic goods; low growth } \\
\text { Elastic goods; high growth }\end{array}$ & same & $\begin{array}{l}-2.71 \\
-1.56\end{array}$ & 0.132 & unequal & $\begin{array}{l}1.39 \\
0.60\end{array}$ & 0.302 \\
\hline $\begin{array}{l}\text { Low growth; short transition period } \\
\text { Low growth; long transition period }\end{array}$ & same & $\begin{array}{l}0.17 \\
1.40\end{array}$ & 0.162 & unequal & $\begin{array}{r}1.00 \\
-2.36\end{array}$ & 0.108 \\
\hline $\begin{array}{l}\text { High growth; Short transition period } \\
\text { High growth; long transition period }\end{array}$ & same & $\begin{array}{l}-0.00 \\
-1.24\end{array}$ & $0.080^{*}$ & same & $\begin{array}{r}0.07 \\
-1.04\end{array}$ & 0.294 \\
\hline $\begin{array}{l}\text { Short transition period; low growth } \\
\text { Short transition period; high growth }\end{array}$ & same & $\begin{array}{r}0.17 \\
-0.00\end{array}$ & 0.446 & unequal & $\begin{array}{r}1.0 \\
0.07\end{array}$ & 0.351 \\
\hline $\begin{array}{l}\text { Long transition period; low growth } \\
\text { Long transition period; high growth }\end{array}$ & same & $\begin{array}{r}1.40 \\
-1.24\end{array}$ & $0.000^{*}$ & same & $\begin{array}{l}-2.36 \\
-1.04\end{array}$ & 0.283 \\
\hline $\begin{array}{l}\text { Low growth; Direct redenomination } \\
\text { Low growth; Gradual redenomination }\end{array}$ & same & $\begin{array}{l}0.37 \\
1.05\end{array}$ & 0.289 & same & $\begin{array}{r}-0.14 \\
-1.2\end{array}$ & 0.353 \\
\hline $\begin{array}{l}\text { High growth; Direct redenomination } \\
\text { High growth; Gradual redenomination }\end{array}$ & unequal & $\begin{array}{r}-1.38 \\
0.14\end{array}$ & $0.042^{*}$ & same & $\begin{array}{l}-0.45 \\
-0.52\end{array}$ & 0.486 \\
\hline $\begin{array}{l}\text { Direct redenomination; low growth } \\
\text { Direct redenomination; high growth }\end{array}$ & unequal & $\begin{array}{r}0.37 \\
-1.38\end{array}$ & $0.060^{*}$ & same & $\begin{array}{l}-0.14 \\
-0.45\end{array}$ & 0.445 \\
\hline $\begin{array}{l}\text { Gradual redenomination; low growth } \\
\text { Gradual redenomination; high growth }\end{array}$ & same & $\begin{array}{l}1.05 \\
0.14\end{array}$ & 0.182 & same & $\begin{array}{r}-1.2 \\
-0.52\end{array}$ & 0.599 \\
\hline $\begin{array}{l}\text { Inelastic; short transition period } \\
\text { Inelastic; long transition period }\end{array}$ & same & $\begin{array}{r}-0.33 \\
0.94\end{array}$ & 0.190 & same & $\begin{array}{l}-0.6 \\
-4.0\end{array}$ & 0.138 \\
\hline $\begin{array}{l}\text { Elastic; short transition period } \\
\text { Elastic; long transition period }\end{array}$ & same & $\begin{array}{r}0.50 \\
-0.92\end{array}$ & $0.002^{*}$ & unequal & $\begin{array}{l}1.39 \\
0.60\end{array}$ & 0.302 \\
\hline $\begin{array}{l}\text { Short transition period; inelastic } \\
\text { Short transition period; elastic }\end{array}$ & same & $\begin{array}{r}-0.33 \\
0.50\end{array}$ & 0.262 & unequal & $\begin{array}{l}-0.6 \\
1.39\end{array}$ & 0.224 \\
\hline $\begin{array}{l}\text { Long transition period; inelastic } \\
\text { Long transition period; elastic }\end{array}$ & same & $\begin{array}{r}0.94 \\
-0.92\end{array}$ & $0.010^{*}$ & unequal & $\begin{array}{r}-4.00 \\
0.60\end{array}$ & $0.023^{*}$ \\
\hline $\begin{array}{l}\text { Inelastic; direct redenomination } \\
\text { Inelastic; gradual redenomination }\end{array}$ & Same & $\begin{array}{l}0.59 \\
1.39\end{array}$ & $0.080^{*}$ & same & $\begin{array}{l}-1.5 \\
-3.1\end{array}$ & 0.308 \\
\hline $\begin{array}{l}\text { Elastic; direct redenomination } \\
\text { Elastic; gradual redenomination }\end{array}$ & unequal & $\begin{array}{l}-1.52 \\
-3.09\end{array}$ & 0.358 & same & $\begin{array}{l}0.60 \\
1.39\end{array}$ & 0.301 \\
\hline $\begin{array}{l}\text { Direct redenomination; inelastic } \\
\text { Direct redenomination; elastic }\end{array}$ & Same & $\begin{array}{r}0.59 \\
-1.52\end{array}$ & 0.364 & unequal & $\begin{array}{l}-1.5 \\
0.60\end{array}$ & 0.185 \\
\hline $\begin{array}{l}\text { Gradual redenomination; inelastic } \\
\text { Gradual redenomination; elastic }\end{array}$ & same & $\begin{array}{r}1.39 \\
-3.09\end{array}$ & $0.076^{*}$ & unequal & $\begin{array}{l}-3.1 \\
1.39\end{array}$ & $0.042^{*}$ \\
\hline $\begin{array}{l}\text { Short transition; direct redenomination } \\
\text { Short transition; gradual redenomination }\end{array}$ & Same & $\begin{array}{r}-0.83 \\
1.00\end{array}$ & $0.077^{*}$ & same & $\begin{array}{r}0.94 \\
-0.17\end{array}$ & 0.336 \\
\hline $\begin{array}{l}\text { Long transition; direct redenomination } \\
\text { Long transition; gradual redenomination }\end{array}$ & Same & $\begin{array}{r}-0.18 \\
0.20\end{array}$ & 0.327 & same & $\begin{array}{l}-1.88 \\
-1.53\end{array}$ & 0.560 \\
\hline $\begin{array}{l}\text { Direct redenomination; short transition } \\
\text { Direct redenomination; long transition }\end{array}$ & Same & $\begin{array}{l}-0.83 \\
-1.18\end{array}$ & 0.283 & same & $\begin{array}{r}0.94 \\
-1.88\end{array}$ & 0.115 \\
\hline $\begin{array}{l}\text { Gradual redenomination; short transition } \\
\text { Gradual redenomination; long transition }\end{array}$ & same & $\begin{array}{l}1.00 \\
0.20\end{array}$ & 0.212 & same & $\begin{array}{l}-0.17 \\
-1.53\end{array}$ & 0.303 \\
\hline
\end{tabular}

note : * significant on 10 percent

source : Data processed (2017) 
Significant conditions when conditions of high economic growth and low economic growth in inelastic goods (Table 1). Redenomination policies that are implemented on low economic growth tend to increase 1.38 percent, while in high economic growth conditions increase the transaction price of 0.59 percent. These results reinforce that high economic growth conditions are ideal conditions for implementing redenomination policies. Based on Table 1, the transition period depends on the growth in which the redenomination policy applied to high economic growth conditions with a fast transition period causes the transaction price to increase by 0.01 percent, while in the redenomination done with the long transition period the transaction price decreases by 1.24 percent. It can be concluded that the long transition period is better used to implement the redenomination policy. Other conditions also affect the redenomination policy. There is a difference in the effect of changes in transaction prices on low and high growth conditions when the long transition period. On the condition of low economic growth, redenomination policy has increased transaction price by 1.40 whereas in high economic growth condition it has decreased transaction price by 1.24 percent. This shows that redenomination policy will be better on long transition period and high economic growth conditions.

Changes in transaction price due to the redenomination stage based on Table 1 depend on the type of goods applied (there is interaction). The influence of groups of direct and gradual stages of redenomination differs significantly from transaction prices when high growth. On the condition of high economic growth redenomination policy is done gradually is has lower transaction price by 0.14 percent, while redenomination on conditions of high economic growth is done directly tend to reduce the price of 1.38 percent. This indicates that the redenomination policy performed directly is better than the gradual redenomination policy.

Furthermore, there are differences in the effect on transaction price on low and high growth conditions when redenomination is done directly. The price of transactions on the redenomination policy conducted directly on the condition of low economic growth tends to increase the transaction price of 0.37 percent. While redenomination policy on high economic growth conditions decreased the transaction price by 1.38 percent. This result indicates that good condition is redenomination policy which is done directly with the condition of high economic growth.

Based on Table 1 the influence of the transitional period depends on the type of goods. The effect of redenomination policy that is done with a fast and long transition period on elastic goods is significantly different from the transaction price. The redenomination policy applied to elastic goods with a fast transition period causes an increase in transaction price by 0.50 percent while in the elastic goods with long transition period causes a price reduction of 0.92 percent. This suggests that the long transition period is a good condition for implementing redenomination policies.

Then, to see the effect when redenomination policies applied to long transitional periods also depend on the type of goods (Table 1). For this type of inelastic goods, after redenomination experienced a transaction price increase of 0.94 percent, while the change in transaction price after redenomination on elastic goods with long transition period decreased 
by 0.92 percent. The results are in line with previous studies, although previous studies (Astrini, 2014; and Pambudi et al, 2015) have not included transition factor factors.

Changes in transaction price due to the redenomination stage based on Table 1 depend on the type of goods (there is interaction). Redenomination policies that apply to this type of inelastic goods are better to use the redenomination stage directly. This is because when using the redenomination stage directly the price of inelastic goods transactions has a lower transaction price change compared to using redenomination gradually that is equal to 0.59 , whereas when gradually causing a rise in transaction price of 1.39 percent. On the other hand, there is a significantly different effect between inelastic goods and elastic goods on the redenomination done gradually. Redenomination gradually on the type of inelastic goods, then the price of inelastic goods tend to increase after redenomination policy that is 1.39 percent while the transaction price decreased by 3.09 percent.

Also, there is a significant influence on the redenomination stage factors that depend on the transition period. In the policy made with the transition period would be better if using the stages of redenomination directly. This is indicated by the percentage change in transaction price decreased when using direct redenomination stage that is equal to 0.18 , whereas in redenomination gradually the price of transactions after redenomination increased by 1 percent. In addition to seeing the effects of economic growth, the type of goods, the transition period and the redenomination stage of the transaction price, also see the effect on the number of transactions, especially for the redenomination policy of four zeroes. Based on Table 1 Influence of type of goods on the number of significant transactions. Table 1 shows that between elastic and inelastic goods have different effects on the number of transactions. On inelastic goods, the number of transactions after the redenomination policy tends to decrease. This is because the seller tends to increase the transaction price after redenomination; this makes the permit of the inelastic goods decreased by 2.1 percent. For elastic goods, the number of transactions increased by 0.99 percent. Declining transaction prices caused the increase in the number of transactions that occurred after redenomination.

Also, the effect on the number of transactions caused by the type of goods depends on growth (Table 1). In low growth conditions, the effect of inelastic and elastic goods also has the consistency of results, where inelastic goods decreased by 2.7 percent, while in elastic goods increased by 1.39 percent. Similarly, when redenomination is done using a long transition period, the effect of inelastic goods on the number of transactions also causes a decrease of 4 percent, while for elastic goods causes an increase of 0.6 percent.

The same thing is consistent when the effect of redenomination stage is done gradually on the inelastic and elastic goods. The redenomination policy gradually leads to significant different effects on the number of transactions on the type of goods (inelastic and elastic). The decline in the number of transactions on the type of inelastic goods occurred that is equal to 3.1 percent. Conversely, the type of elastic goods increased by 1.39 percent. This study consists of 32 countries that have implemented redenomination policy. Among these countries, there are successful and failed states (See Appendix). Success and fail of the country to implement redenomination policies based on inflation data and economic growth a year before and after redenomination (inflation down and economic 
growth increased). Independent variables are taken from 1963 to 2008 which is illustrated by a country's condition when implementing redenomination policy.

Based on Table 2, it appears that $\mathrm{R}^{2}$ for the succeed and fail of the state model to redenominate is 86.3 percent, this means that 86.3 percent of redenomination success variables can be explained by all independent variables in the model while the rest is explained by other factors not found in the model. Based on the significance test influencing the success of the redenomination policy with the probability value below 1 percent real level is the economic growth in the year applied redenomination and unemployment rate in the year applied redenomination. Also, a country's democratic index is significantly below 5 percent.

Table 2 Factors that affect the success of redenomination

\begin{tabular}{cccc}
\hline Variable & B & Sig. & Odds Ratio $\operatorname{Exp}(\mathrm{B})$ \\
\hline Constant & 3.136 & 0.102 & 23.635 \\
Inflation rate & -1.025 & 0.173 & 0.359 \\
Economic growth rate & 0.124 & $0.004^{*}$ & 1.132 \\
Interest rate & -0.571 & 0.774 & 0.565 \\
Money growth & 1.046 & 0.997 & 2.848 \\
Unemployment rate & -0.937 & $0.016^{* *}$ & 0.392 \\
Democratisation & 0.034 & $0.005^{*}$ & 1.035 \\
\hline R-square & 0.863 & &
\end{tabular}

Note: $\mathrm{Y}=$ The state's success in applying redenomination policies (worth 1 for "succeed" and 0 for "failure"). ${ }^{* *}$ Significant on $5 \%$; *Significant on $1 \%$

source : Data processed (2017)

The economic growth variable has an odds ratio of 1.132 , meaning that the chance of success of the state to redenominate policy on the condition of high economic growth is 1.132 times more significant than the country with low economic growth condition ceteris paribus. The higher the rate of economic growth of a country, the higher successful opportunity to implement redenomination policy. These results also support the findings of primary research where high economic growth conditions are judged to be better to decrease the transaction price after redenomination.

Besides economic growth, the unemployment rate also has a role in influencing the success of the redenomination policy. The value of odds ratio of 0.392 can be interpreted that the chance of redenomination when the high unemployment rate is 0.392 times smaller than the country when the low unemployment rate. The lower the unemployment rate of a country, the chances of success of a country will be greater. It means that a country has a low unemployment rate when applying redenomination policy is the ideal condition for redenomination policy. The level of democratization has also affected the success of redenomination, the value of the odds ratio of 1.035 means the chances of success of the state on redenomination policy when the democratic government is 1.035 times greater than the low democratic state. The high relation with the democratic country is judged to have a higher chance of success. Democracy has to do with people's trust in the ruling government so that people under democratic government are more receptive to policies by the government, one of which is redenomination policy. 


\section{Conclusion}

From the results of the research, the policy implications of redenomination on transaction prices by using economic experiments that redenomination policies are good at doing in conditions of high economic growth, the stages of redenomination directly and by using the transition period. Also, the nature of inelastic good after the redenomination policy tends to lead to increased transaction price and decrease in the number of transactions while the opposite for elastic products after redenomination tends to lead to a decrease in transaction prices and an increase in the number of transactions.

Also, if low inflation and high economic growth measure the success of redenomination policy, redenomination success tends to be influenced by economic conditions when a country applies its currency redenomination. Countries that implement redenomination policies when high economic growth are low unemployment and high levels of democratization have the chance of success rate in implementing redenomination policies. Redenomination policy should be done when the economic and political conditions are stable, especially during high economic growth, redenomination policy is done directly, using the transition period and done when the country has a low unemployment rate as well when the level of democratization of a country high. Future research is expected to extend the range of response effects and add other factors, thus providing a more realistic picture of the impact of redenomination policies on the economy.

\section{References}

Astrini, D.A. (2014). The Impact of Redenomination on Economic Performance: Experimental and Historical Approach. (Unpublished Thesis). Bogor: Bogor Agricultural University.

Dzokoto, V., Edwin, C., Maxwell, T., \& Annabella, O. (2010). Deceiving Our Minds: A Qualitative Exploration of the Money Illusion in Post-redenomination Ghana. Journal Of Consumer Policy. Vol. 33(4): 339-353. doi: https://doi.org/10.1007/s10603-0109144-3.

Hobijn, B., Ravena, F., \& Tambalotti, A. (2006). Menu Costs at Work: Restaurant Prices and the Introduction of the Euro. The Quarterly Journal of Economics. Vol. 121 (3): 11031131. doi: https://doi.org/10.1162/qjec.121.3.1103.

Juanda, B. A. (2009). Metodologi Penelitian Ekonomi dan Bisnis (Research Methodology fro Economics and Business). Bogor: IPB Press.

Juanda, B. A. (2011). Ekonomi Eksperimental untuk Pengembangan Teori Ekonomi dan Pengkajian Suatu Kebijakan (Experimental Economics for Development of Economic Theory and Assessment of a Policy). Bogor: IPB Press.

Mahardika, H., Agung, Y., \& Erita, N. (2015). Adapting to Zeroes: Investigating The Need for a Transition Period in The Proposed Rupiah Redenomination plan. Journal International Business and Entrepreneurship Development. Vol. 8(4): 1-16. doi: https:// doi.org/10.1504/JIBED.2015.072925.

Mattjik, A. A., \& Sumertajaya, I. M. (2002). Experimental Design with SAS and MINITAB Applications. Bogor: IPB Press. 
Mehdi, S., \& Motiee, R. (2012). An Investigating Zeros Elimination of the National Currency and Its Effect on National Economy (Case study in Iran). European Journal of Experimental Biology. Vol. 2 (4):1137-1143

Mosley, L. A. (2005). Dropping Zeros, Gaining Credibility? Currency Redenomination in Developing Nations. Working Paper of Annual Meeting of The American Political Science Association, Washington DC.

Pambudi, A., Bambang, J \& Priyarsono, D. (2015). Determinants of Redenomination Currency Hygiene: Historical and Experimental Approach. Bulletin of Monetary and Banking Economy. Vol. 2 (1): 1-30.

Zidek, L., \&Michal, C. (2015). Impact Currency Redenomination On Inflation Case Study Turkey. Asian Economic an Financial Review. Vol. 5(6): 908-914.

\section{Appendix}

The List of Countries that Done the Redenomination

\begin{tabular}{|c|c|c|c|c|c|c|c|}
\hline \multirow{2}{*}{ No } & \multirow{2}{*}{$\begin{array}{c}\text { Year of } \\
\text { redenomination }\end{array}$} & \multirow{2}{*}{ Country } & \multicolumn{2}{|c|}{ Inflation } & \multicolumn{2}{|c|}{ Growth } & \multirow{2}{*}{ Explanation } \\
\hline & & & Before & After & Before & After & \\
\hline 1 & 1999 & Angola & 107.285 & 248.200 & 6.805 & 3.012 & failed \\
\hline 2 & 1992 & Argentina & 171.672 & 24.900 & 12.670 & 5.907 & success \\
\hline 3 & 2006 & Azerbaijan & 9.680 & 8.400 & 26.400 & 25.049 & failed \\
\hline 4 & 2000 & Belarus & 2.573 & 168.600 & 3.400 & 4.725 & failed \\
\hline 5 & 1987 & Bolivia & 276.336 & 14.600 & -2.574 & 2.910 & success \\
\hline 6 & 1994 & Brazil & 1927.983 & 147.98 & 4.665 & 4.417 & success \\
\hline 7 & 1999 & Bulgaria & 18.672 & 2.600 & 3.500 & 5.011 & success \\
\hline 8 & 1981 & Chile & 504.734 & 374.735 & 2.382 & 3.833 & failed \\
\hline 9 & 1998 & Congo & 16.700 & 3.600 & -0.625 & -2.582 & failed \\
\hline 10 & 1963 & Finland & 10.357 & 4.865 & 2.982 & 5.239 & success \\
\hline 11 & 1995 & Georgia & 310.750 & 162.700 & 5.427 & 11.200 & success \\
\hline 12 & 2007 & Ghana & -1.409 & 9.161 & 6.400 & -1.698 & failed \\
\hline 13 & 1985 & Iceland & 58.546 & 50.900 & 5.748 & 2.155 & failed \\
\hline 14 & 1985 & Israel & 373.821 & 304.600 & 0.904 & 4.791 & failed \\
\hline 15 & 1994 & Croatia & 1494.684 & 107.150 & 2.900 & 2.940 & success \\
\hline 16 & 1993 & Latvia & 243.267 & 108.768 & 2.700 & 2.190 & failed \\
\hline 17 & 1993 & Lithuania & 305.970 & 410.241 & 2.810 & -9.770 & failed \\
\hline 18 & 1993 & Macedonia & 11.820 & 0.544 & -6.565 & -1.758 & success \\
\hline 19 & 1993 & Mexico & 15.509 & 9.800 & 3.629 & 4.727 & success \\
\hline 20 & 1993 & Moldova & 315.610 & 18.200 & 2.850 & -30.900 & failed \\
\hline 21 & 2006 & Mozambique & 7.168 & 13.200 & 9.851 & 7.426 & failed \\
\hline 22 & 1988 & Nicaragua & 911.925 & 10205.027 & -0.706 & -1.698 & failed \\
\hline 23 & 1991 & Peru & 7481.664 & 409.500 & -4.983 & -0.541 & failed \\
\hline 24 & 1995 & Poland & 33.252 & 27.900 & 5.293 & 6.057 & success \\
\hline 25 & 2005 & Romania & 11.877 & 9.000 & 8.359 & 8.056 & success \\
\hline 26 & 1998 & Russia & 14.767 & 27.700 & 1.400 & 6.400 & success \\
\hline 27 & 1992 & Sudan & 123.578 & 117.600 & 7.511 & 4.569 & failed \\
\hline 28 & 2005 & Turkey & 10.584 & 8.200 & 7.511 & 7.110 & success \\
\hline 29 & 1987 & Uganda & 160.985 & 200.026 & 0.390 & 8.267 & failed \\
\hline 30 & 1996 & Ukraine & 376.746 & 80.200 & -12.200 & -3.000 & failed \\
\hline 31 & 1993 & Uruguay & 68.459 & 54.100 & 7.932 & 7.281 & failed \\
\hline 32 & 2008 & Venezuela & 18.699 & 2.776 & 8.754 & -3.202 & failed \\
\hline
\end{tabular}

